\title{
The Development and Rationale of Cross-blended Hypsometric Tints
}

Tom Patterson', Bernhard Jenny²

tom_patterson@nps.gov, jennyb@geo.oregonstate.edu

'US National Park Service,
Harpers Ferry, WV, USA

${ }^{2}$ Oregon State University,

Corvallis, OR, USA

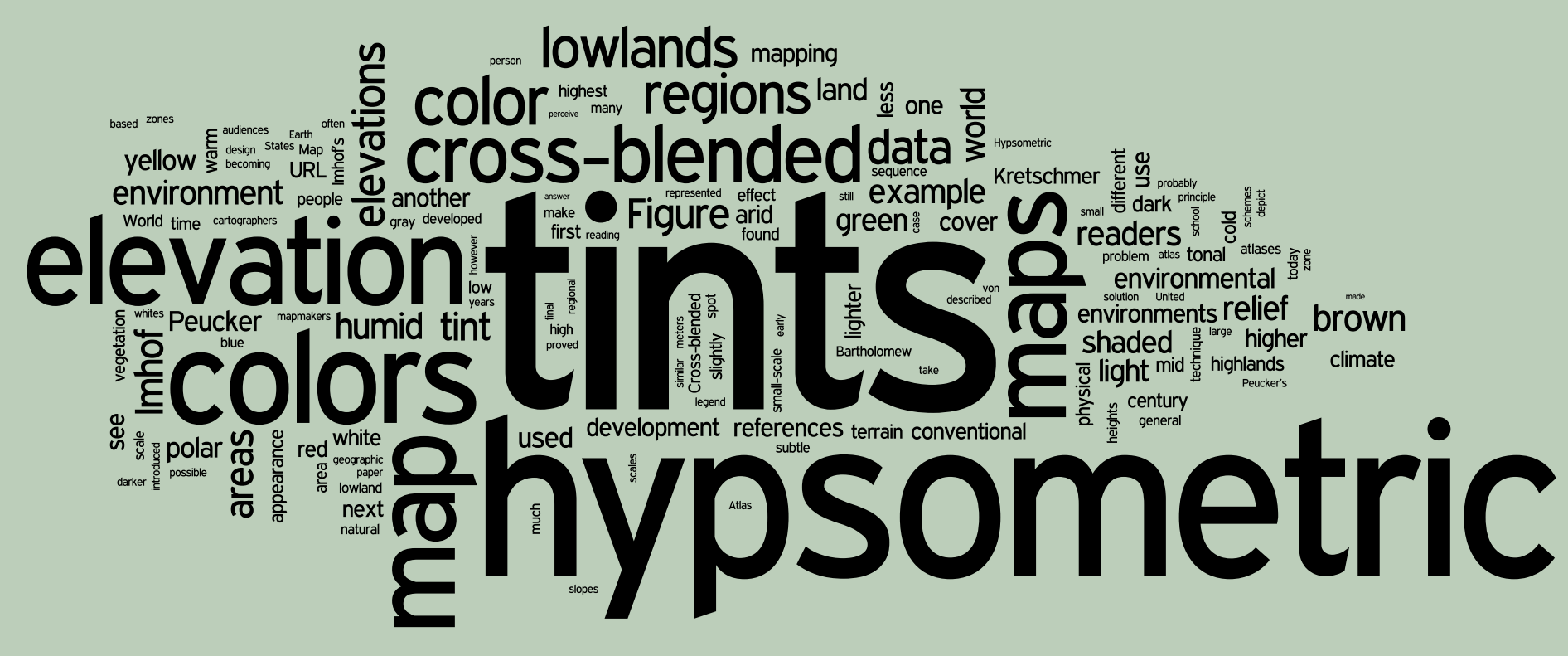

\section{ABSTRACT}

Hypsometric tints have been a favored mapping technique for over 150 years. By the mid-twentieth century, hypsometric tints based on the work of John Bartholomew, Jr., Eduard Imhof, and Karl Peucker became the de facto standard for physical reference maps at small scales. More recently, the role and design of hypsometric tints have come under scrutiny. One reason for this is the concern that people misread elevation colors as climate or vegetation information. Cross-blended hypsometric tints, introduced in 2009 , are a partial solution to this problem. They use variable lowland colors customized to match the differing natural environments of world regions, which merge into one another. In the short time since their introduction, cross-blended hypsometric tints have proved to be a popular choice among professional mapmakers. Most maps made with cross-blended hypsometric tints also contain shaded relief (terrain represented with modulated light and shadows). 


\section{INTRODUCTION}

Hypsometric tints (Imhof 1982) — cartographic jargon for elevation colorshave been a staple of map design since the early- to mid-nineteenth century. From the ocean shore to the highest peaks, they bring to maps the pleasing greens, beiges, yellows, reds, and whites that depict elevation zones in a systematic manner. Although most people are unfamiliar with hypsometric tints as a term, and probably not keenly interested in elevation zones, they have likely admired these colors on wall maps in homes, offices, and classrooms. They are still widely used today in a diverse range of products, including atlases, airline in-flight maps, television weather maps, and wall maps. Many a cartographer has made a living meeting the demands of this market.

The market success of hypsometric tint maps, however, does not necessarily correspond with reader understanding. There is general concern in the mapping community that students and other inexperienced map readers confuse hypsometric tints with environmental phenomena (Wiegand 2006) such as vegetation, land cover, and climate. The evidence is mostly anecdotal. The classic example is a typical hypsometric tint map that applies dark green-the standard hypsometric tint for low elevation-to the shores of the Persian Gulf. Because green is the color of growing vegetation, some readers may wrongly perceive this sere region as having luxuriant forest or intense cultivation.

This paper discusses the development and rationale of cross-blended hypsometric tints as a partial remedy for the potential problem just described (Figure 1). These new tints depict elevations on small-scale maps in a manner that can take into account regional environmental differences. A pragmatic "if you can't beat them, join them" approach served as the basis for developing cross-blended hypsometric tints. If readers often get elevation colors confused with the environment, then why not cater to this predisposition by having them represent both?
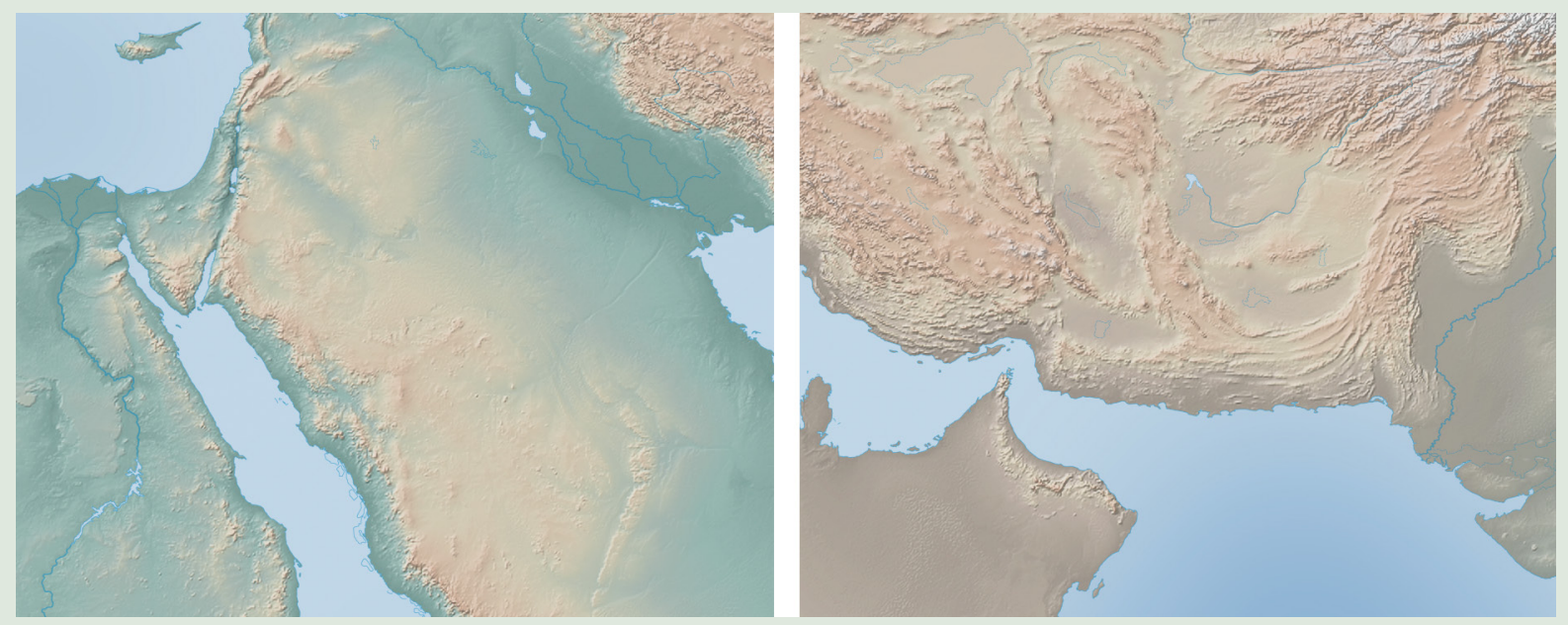

Figure 1. Conventional hypsometric tints (left) use a green lowland tint everywhere, suggesting that southwest Asia is lush (shaded relief has also been applied). Cross-blended hypsometric tints (right) use varying lowland colors tailored to specific regional environments, in this case arid land. 
Cross-blended hypsometric tints are a variant of the more-or-less conventional hypsometric tints that emerged in the mid-twentieth century from a disparate range of prior tint schemes, some with origins in the nineteenth century. To better understand why cross-blended hypsometric tints look the way they do and the factors influencing their development, one must look back to an even earlier time.

Perhaps the first map with hypsometric tints is Leonardo da Vinci's Map of Central Italy, c. 1503-04 (see references for URL). This manuscript map has indistinct brown tints applied with washes and chalk that depict elevation differences. Darker browns represent higher elevations. Leonardo da Vinci's map almost certainly does not derive from surveyed elevation data. Nevertheless, in an era when terrain on maps typically appeared as humpshaped mountain drawings, his technique was a major advancement, predating other hypsometric tint maps by three centuries. The next phase of hypsometric tint development would have to wait until scientists started collecting surveyed elevation data.

With the development of the barometer around 1800, measuring elevations became possible, which resulted in the compilation of lists of spot heights. In France, François Pasumot was probably the first to publish a "table comparative" in 1783 with 83 spot heights (Engelmann 1966). Various contemporary scientists compiled tables with spot heights, including such geographic notables as Alexander von Humboldt, Carl Ritter, and Wolfgang von Goethe (Kretschmer 1986 and 1988). Contemporaneously with collecting spot heights came development of new methods to visualize them. These methods included cross-sectional profiles, and on maps, labeled spot heights and interpolated contour lines, particularly on large-scale maps.

Coloring the area between contours was the logical next step in visualizing elevation. French engineer Jean Louis Dupain-Triel is the first to have done this on a contour map produced in 1791, which he later modified to include elevation tinting (Thrower 2008). Austria was an early center of hypsometric tint innovation. In the late 1820s, Franz von Hauslab drew manuscript maps with elevations represented as color layers. The widespread adoption of his technique started a decade later with the advent of chromolithography, the first color printing technology. Hypsometric tint maps soon afterwards became popular for school maps, atlas plates, and other types of small- and mediumscale maps-it was a reign that would last until the end of the twentieth century and the advent of natural color maps based on satellite land cover data (Patterson and Kelso 2004).

The years between 1840 and 1870 were a pivotal time for hypsometric tint development (Kretschmer 1986). Two categories of tints emerged then that have relevance to modern mapmaking: 
Polychromatic tints: Also known as spectral tints, early maps with this scheme used a series of colors selected for maximum contrast in an unmethodical arrangement. A classic map of this type is August Papen's "HöhenSchichtenkarte von Central-Europa" [layer tints map of Central Europe], published 1857-1859. The assignment of colors to elevation zones on this map would puzzle contemporary readers-for example, Papen uses blue to depict a middle elevation (Figure 2A). The overall effect is not unlike the diverging "rainbow" colors used today by scientists for computer-generated visualizations. Imhof (1982) states that with these contrasting color schemes the continuity of the terrain is lost, and the combination with other map features is difficult. Because printing a large number of colors proved expensive, cartographers began replacing spectral sequences with more systematic schemes by the midnineteenth century (Kretschmer 2000).

Continuously progressing tints: Tonal tints is another name for this category. Reacting to unstructured polychromatic tints, cartographers developed a more orderly and cheaper alternative by varying the intensity of a single color tone or ink, typically gray or brown (Figure 2B). For example, cartographers in Leipzig, Germany, preferred brown for school and wall maps, modifying that color according to "the higher, the darker" principle (Kretschmer 2000). Placing lighter tones in lowlands serves a practical purpose. Because lowlands generally cover more area than highlands on small-scale maps, and a greater density of map labels is generally found in lowlands, placing lighter tints there improves overall legibility. Despite this advantage, later the practice of combining shaded relief and hypsometric tints proved the death knell for "the higher, the darker" tints. Printing dark shadows over dark tints results in excessively dark mountains that dominate all else on the map, illegible or poorly legible labels, and the lack of a three-dimensional appearance. Today, most hypsometric tints employ "the higher, the lighter" principle to avoid this problem —although the relatively dark lowlands are less than ideal when combined with other map information.

The elevation tints introduced in 1878 by Scottish cartographer John Bartholomew, Jr. (1831-1893), were the next major development (Figure 2C). Bartholomew's colors have a decidedly modern appearance, ranging from delicate greens and tans in the lowlands to rich orange-browns and purples in the highlands to white on the loftiest peaks (Gardiner 1976). His hypsometric tints were not an instant success. According to Gardiner (1976, 25):

"Cartographers of the period, notoriously conservative, seemed to consider it a catchpenny trick, liable to take the mystique out of geography and make it intelligible to laymen."

And that is precisely what happened. Within twenty years, hypsometric tints were widely adopted by atlas publishers everywhere. Bartholomew \& Sons, Ltd. employed a variant of their tints on Times atlases, becoming a hallmark of those influential reference works.

\section{BECOMING CONVENTIONAL}

The early-to-mid twentieth century was a time of intense debate by academic cartographers over which elevation colors best gave terrain a three-dimensional 
appearance on a flat sheet of paper. "Farbenplastik" (color plasticity) was the term then used for this desired effect (Kretschmer 1988). Two competing schools rose to the forefront of the debate. Karl Peucker (1859-1940), from Vienna, was among the first to systematically analyze the use of elevation tints (Figure 2D). He distinguished colors according to their brightness, saturation, and hue. Peucker proposed the principle "the higher, the richer the color," starting with dull gray-green in the lowlands and ending with bright red in the highlands (Kretschmer 2000). Peucker selected these colors based on supposed physical and physiological considerations, as well as on real-world observations (Imhof 1982). His "sequence should give an optical stereographic impression," which would "increase the impression of plasticity" (Kretschmer 1986). Peucker's assumption was that certain colors would appear closer to the eye than other colors that would have the opposite effect and appear further away. Many have heavily criticized this assumption. For example, Eduard Imhof (1895-1986) questioned Peucker's mathematical and physical bases for his claims (Imhof 1924; 1982, pp. 304-305), but agreed with Peucker that a hypsometric color sequence should imitate the effect of aerial perspective, which attenuates more distant lowland colors (Kretschmer 1988).

Imhof, from Switzerland, favored a green (or blue green), light yellow green, light yellow red, and white progression from low to high (Figure 2E). He developed these tints in 1962 for the "Schweizerischer Mittelschulatlas" (Swiss Middle School Atlas). Imhof's tints are notable for being both spectral and tonal. Unlike Peucker who has a discontinuous bright yellow tint at mid elevations, Imhof's more subtle tints progress evenly from dark lowlands to light highlands. Taking this idea even further, he advocated doing away with layered steps in favor of smooth blends to improve topographic modeling. The aerial perspective effect, which suggests lowlands partially veiled by a light bluish haze, is another trait of Imhof's tints (Imhof 1982).

Looking back from today, neither Peucker nor Imhof completely won the hypsometric tint war. Peucker's tints in their original form are now rarely, if ever, used. Imhof's tints are still widely used in Switzerland, including the most recent edition of the Schweizer Weltatlas (the current edition of the school atlas initiated by Imhof), but less so elsewhere. What has happened instead is a general synthesis of their styles, exemplified by the 1962 International Map of the World (Figure 2F and G). The lower elevation colors on this 1:1,000,000-scale map series are much like Imhof's, starting with light bluegreen that transitions upwards to yellow. And, in a nod to Peucker, medium red-brown depicts mid elevations; however, this scale does not end with redbrown. It introduces light gray-violet at next highest level and finally ends with white. The addition of these last two colors suggests the earlier influence of John Bartholomew, Jr.

The hypsometric tints developed for the International Map of the World have become commonplace, even conventionalized. Today, one sees variants of these tints in The DK World Atlas, Goode's World Atlas, Raven Maps, and countless other maps published worldwide. This popularity, however, comes with a compromise. The tints just described abandon the principles underlying Imhof and Peucker's originals. The sequence of colors is not perfectly tonal-they do not blend evenly from dark to light-nor does rich red occupy the highest elevation. These tints clearly show their mixed pedigree. 
Imhof $(1982,300)$ noted the tendency of mapmakers to select hypsometric tints arbitrarily:

"Objective considerations alone have not always been the deciding factors. Tradition, partiality and whim, preconceived opinions, aesthetic sensitivity or barbarity of taste often play leading roles in the selection of colors."

His observation was prescient. With the ongoing democratization of cartography, an "anything goes" approach to hypsometric tints has emerged. The combination of free elevation data and easy-to-use software has swelled

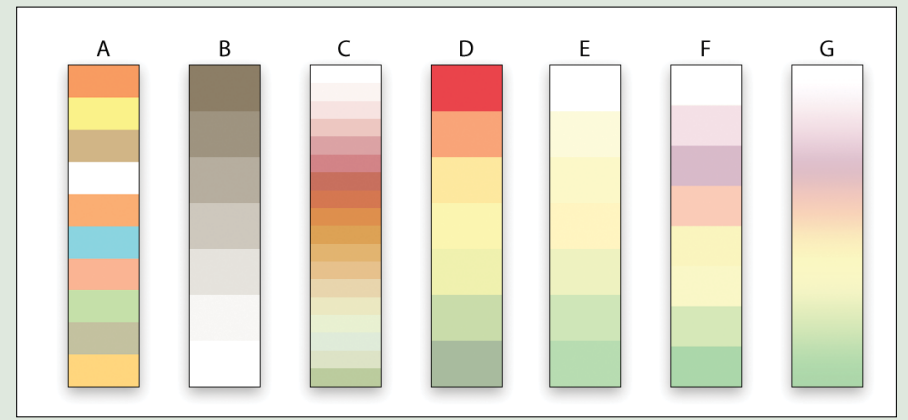

Figure 2. Hypsometric tints: A) August Papen's polychromatic tints, B) Continuously progressing tints - higher is darker, C) John Bartholomew Jr.'s tints, D) Karl Peucker's tints, E) Eduard Imhof's tints, F) International Map of the World tints, and G) International Map of the World tints as a gradient. Illustration primarily adapted from Imhof, 1982. The Bartholomew tints derive from Gardiner, 1976. Note that the illustration colors vary somewhat from the originals.

the ranks of amateur mapmakers, some who willfully make maps with unorthodox colors (Chilton 2007. See references for URL). Creating visual drama is often the chief objective.

The development of so many hypsometric tint styles has come with a large number of terms describing them, which are loosely used. General terms for hypsometric tints include scales, sequences, series, and progressions. More specifically, blends, gradients, and ramps usually refer to smoothly transitioning tints with no discernible breaks (Figure 2G). And intervals, layers, and steps are terms referring to discrete elevation zones that contrast with one another (Figure 2A-F).

\section{MORE THAN ELEVATION}

The premise of this paper, that map readers could mistake hypsometric tints for climate or vegetation, was not a concern of Imhof and Peucker. Why not? The possible answers to this question shed light on why hypsometric tints have become less popular today. 
First, both men were a product of their time, and - for maps at medium and small scales-focused on mapping terrain alone. During their early careers, national topographic surveys were delivering accurate elevation data for the first time; therefore, finding ways to visualize these data on maps took precedence. The tints that they devised achieved this singular objective very well. Because global vegetation and land cover data were not available in their day, it was reasonable for them to assume that readers would not mistake elevation colors for a data type that did not yet exist.

Second, their choice of elevation tints is at least partially related to the natural environment in which they lived (Thrower 2008). For example, Imhof's tints generally mimic the colors observed in the Alps, a region of lush valleys and glacier peaks illuminated by warm alpenglow from the setting sun. Green lowlands, yellow mid elevations, and white highlands are logical color choices for that location. Nonetheless, one must wonder if they had lived in places with markedly different physical environments-Phoenix, Reykjavik, or Nairobiwhether their color schemes would have been different. Would brown or gray now be the standard lowland color?

Third, they lived in countries that take geographic education seriously and teach map reading in schools-for example, every Swiss middle school student receives a world atlas. Regardless of which hypsometric tints were used on maps, they could expect that their fellow citizens would learn what they meant.

The possible reasons for why Imhof and Peucker focused exclusively on mapping elevation are no longer as valid today. There is now an abundance of climate, land cover and vegetation data covering the entire world. Thus, map publishers have an alternative to hypsometric tints for small-scale physical mapping by combining land cover with shaded relief. However, land cover colors - green, yellow, brown, and white-are similar to those used for hypsometric tints, which could confuse readers. As a result, Oxford University Press-Australia \& New Zealand has recently abandoned hypsometric tints in favor of land cover for the physical maps in their student atlases (see references for URL).

Another consideration is the lack of commitment to geographic education in much of the developed world, particularly the United States, according to the 2006 National Geographic-Roper Survey of Geographic Literacy (see references for URL). Cartographers cannot assume as they once did that their audiences have had training on how to read hypsometric tints. Research indicates that many US students also perceive elevation colors as representing environmental phenomena (Patton and Crawford,1978). The many maps with hypsometric tints and with no legend identifying them-for instance, TV weather maps-only increase the potential for confusion.

Despite these recent trends that argue against the continued use of hypsometric tints, this venerable map type may still be relevant to modern audiences in the modified form described next. 


\section{CROSS-BLENDED HYPSOMETRIC TINTS}

Unlike conventional hypsometric tints that apply a single sequence of elevation colors uniformly to all areas of a map, cross-blended tints vary from place to place depending on the regional environment. They attempt to indicate both elevation and colors that people presumably associate with the natural environment. On a world map with cross-blended hypsometric tints, for

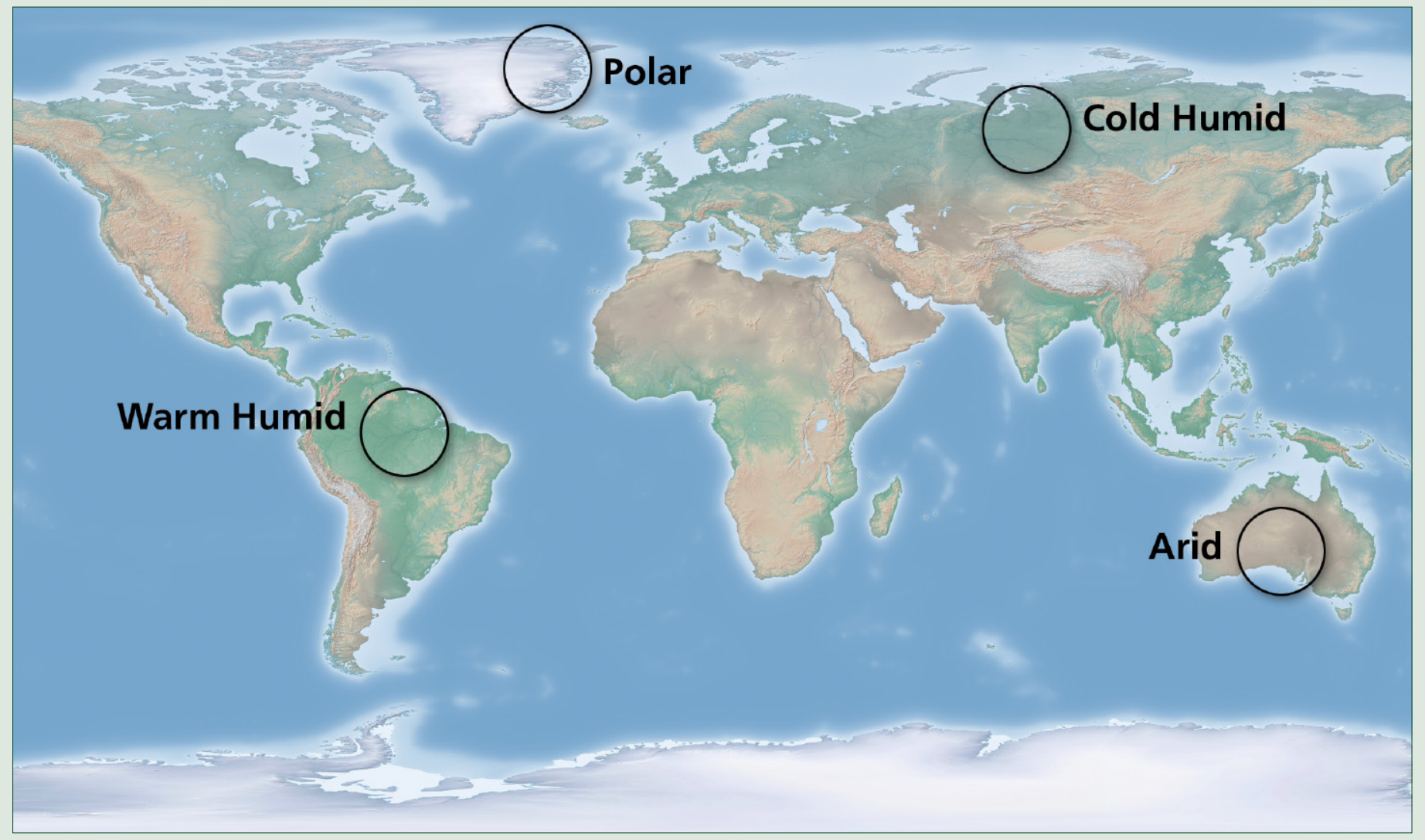

Figure 3. Cross-blended hypsometric tints combined with shaded relief on a world map. Lowland colors vary according to the generalized natural environment of world regions.

example, interior Australia is dusty brown, western Siberia is boreal forest green, the Amazon basin is jungle green, and Greenland is icy blue-gray. As in nature, the map colors gradually blend into one another across regions ( $\mathrm{x}$ and $\mathrm{y}$ axis) and from lowlands to highlands ( $\mathrm{z}$ axis), hence the name cross-blended hypsometric tints (Figure 3).

A pragmatic "design for all" philosophy guided the development of crossblended hypsometric tints. Most of the world's population receives little or no map reading education. Rather than educating 6.9 billion people on how to read hypsometric tints, a quixotic undertaking unlikely to happen anytime soon, we adapted the tints to match people's preconceptions. The goal was to do what Bartholomew did 133 years earlier: take the mystery out of geography and make it intelligible to laymen (Gardiner 1976). In their portrayal of the world, cross-blended hypsometric tints offer a fusion of elevation and environment 
mapping. This duality recognizes that diverse audiences are likely to perceive hypsometric tints differently. For example, a person identifying the brown tone along the Persian Gulf shore as low elevation is correct; so too is the person who identifies this color as desert. And another person who sees this area as both lowland and desert is doubly correct.

\section{DESIGN AND PRODUCTION}

A pragmatic "design for all" philosophy guided the development of cross-blended hypsometric tints
Cross-blended hypsometric tints are a raster dataset with a color scheme applied to world elevations introduced in 2009. With these data, professional mapmakers can produce small-scale maps intended for general audiences. Cross-blended hypsometric tints are available in multiple sizes, in versions with and without shaded relief, and are downloadable for free. They are available at NaturalEarthData.com, a map data website sponsored by NACIS.

The starting point for production was a world base map with conventional hypsometric tints generated from SRTM30Plus elevation data at 30-arcsecond resolution. The conventional hypsometric tints on this base were similar to those developed for the 1962 International Map of the World, with modifications. Designed to give a relative impression of elevation differences, they use a continuous color ramp with one color blending into the next instead of stepped intervals. Additionally, the yellow found at mid elevations is slightly darker, the red at the next highest elevation is slightly lighter, and, higher still, the gray is much lighter. With these adjustments the sequence of colors conforms more closely with the "higher is lighter" principle of tonal scales. Hypsometric tints applied to elevation values below 1,000 meterswhich comprise most of Earth's total land area-have more tonal variation than do the tints found in higher areas. The Physical Map of the Coterminous United States, a previous project by Patterson (2006), was the first test of these tints (see references for URL). Informal querying of colleagues about their preferences guided the color selection, which was ultimately a subjective decision. (See Appendix A for CMYK and RGB color values).

\section{ENVIRONMENT COMPONENT}

The next step involved changing the ubiquitous green lowlands on the world map to colors that better represent different regional environments. Limiting the environmental regions to only four-warm humid, cold humid, arid, and polar-was a deliberate decision to avoid unnecessary complexity. We judged the cross-blended hypsometric tints as more successful when altitude data rather than environmental data were the primary generators of tonal variation. Representing slightly different environments with slightly different colorssay, shades of yellow representing tropical grassland and tropical savannawas deemed beyond the threshold of recognition. Additionally, shaded relief printing on the subtle cross-blended tints would further obscure their meaning. The four environments depicted on the final map are easily represented by distinctive colors: warm humid regions are rich yellow-green, cool humid 
regions are blue-green, arid regions are khaki brown, and polar regions are cold gray. Each takes up a roughly equivalent amount of land area on Earth's surface.

Determining the fuzzy, generalized boundaries between environmental regions involved references to climate maps in atlases. For example, polar regions are commonly defined as having an average temperature below 10 degrees Celsius for the warmest month of the year, typically July in the northern hemisphere and January in the southern hemisphere. Importing this isotherm as an Adobe Photoshop layer mask and blurring it provided an effective way to map polar environments. Similar methods based on the Köppen-Trewartha climate classification system allowed for the mapping of other environmental regions across the entire Earth (Goode's World Atlas 1983). In the Köppen-Trewartha system, the Af and Am classification designate warm humid (tropical) climates; $\mathrm{Db}, \mathrm{Dc}$, and Dd designate cold humid (continental) climates; and, Bs and Bw designate arid climates (Figure 4). Precipitation maps in atlases aided the identification of arid and humid regions. Attempts at using gridded climate data (Kottek et al. 2006) for production proved less than ideal, because of the excess detail and abrupt boundaries between the climate regions. Depicting environmental regions as broad, generalized swaths is the preferred method for creating cross-blended hypsometric tints.

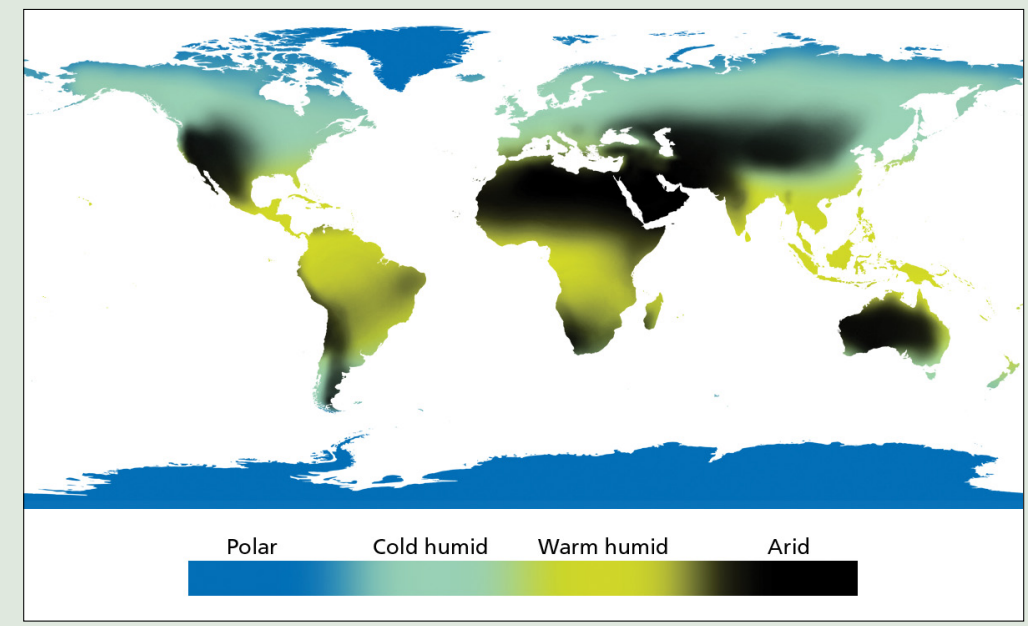

Figure 4. The generalized environment zones depicted with false colors used to create cross-blended hypsometric tints. The fuzzy edges of the zones emulate the transitions that occur naturally.

Using false colors rather than the final cross-blended hypsometric tints to create masks of the four environmental regions made it easier to visualize the subtle transitions (Figure 4).

\section{SELECTING COLORS}

Selecting the regional environment colors required considerable experimentation. The khaki brown used for arid lowlands was particularly challenging. This environment accounts for nearly all land that is below sea level 
on Earth (these low spots tend to fill with water in humid areas, becoming lakes, and with ice in polar areas) ${ }^{1}$. Giving the brown lowlands a value (i.e., darkness) equivalent to that of the green lowlands resulted in vast areas of the world becoming somber and uninteresting. Adding too much red, a color that many map readers associate with upper elevations, to the brown presented the problem of the lowlands no longer appearing as lowlands. In the area north of the Caspian Sea where arid and cold humid lowlands merge, identifying complementary colors was difficult. Taking into account all of these issues, the compromise solution was selecting a neutral brown for the arid lowlands. It is slightly less dark (two percent when converted to grayscale color mode) than the greens found in humid lowlands (Figure 1).

With the exception of polar regions, the different environment colors occur only in areas that are below 1,000 meters in elevation. Above that the hypsometric tints are conventional-and identical, regardless of the environment. Aesthetics were the reason for this compromise decision to preserve the reds, grays, and whites at middle and upper elevation that readers seem to respond to favorably.

In the case of cross-blended

hypsometric tints, the mid- and high-elevation colors are the visual bait that attracts attention. After that, the low elevation colors are there to deliver a subtle message to a potentially large audience- the $74 \%$ of the world's people who live in places under 500 meters in elevation (Cohen and Small 1998). A person reading a cross-blended hypsometric tint map is likely to see his or her home represented by a color that is prevalent in the local environment.

Polar regions are a special case. They differ from all other regions in that they dispense with the yellows, reds, and whites at the upper elevations in favor of a tonal scale ranging from gray-violet lowlands to nearly white highlands. Antarctica and Greenland are unique enough to warrant this special treatment, as warm yellow and

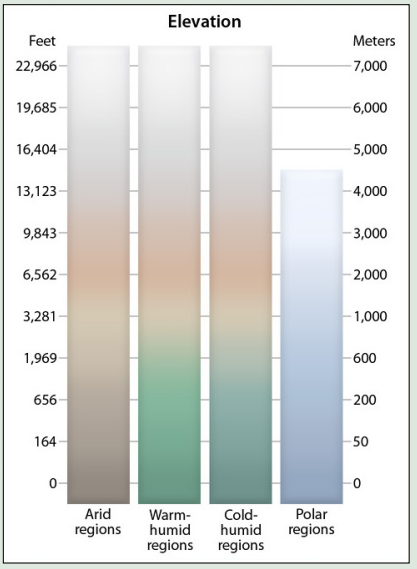

Figure 5. Lowland colors in the first three elevation scales (starting from left) depict generalized environments. Above 1,000 meters the colors are identical and rather conventional. The polar scale (right) uses unrelated colors and is shorter because peaks are below 5,000 meters in these regions. red are inappropriate for an icecap environment. In the past, many conventional hypsometric tint maps sidestepped this problem by representing these regions with a flat white color and a few blue contour lines. Now with cross-blended hypsometric tints, the

${ }^{1}$ The Caspian Sea, which is below mean sea level, is an exception: there is a narrow strip of humid lowland along its southern shore. 
full range of elevation tones is present. And they look appropriately icy. Having these cold colors at high latitudes provides a visual counterbalance to the warm colors dominating the low latitudes. At the fringes of the polar zone in the northern hemisphere, the polar zone merges with the cold humid zone to suggest an intermediate tundra zone. The polar elevation colors do not extend as high as the hypsometric tints of other regions because of the comparatively lower maximum elevations found there (Figure 5).

The grays and whites found at high altitudes elsewhere in the world are similar in appearance to the polar tints, but with less blue, because of their similar environments - both are cold and inhospitable. The high-altitude tints gradually make their appearance above 3,000 meters in the Andes, Himalayas, Tibetan Plateau, mountains of Central Asia, and other lofty areas.

\section{SHADED RELIEF COMPONENT}

The final production step added a light application of shaded relief to the cross-blended hypsometric tints. So as not to muddy the hypsometric tints, the overprinting shaded relief does not contain gray value in flat areas, allowing readers to see the subtle hypsometric variations in these areas as pure colors. Moving to higher ground, shaded relief becomes increasingly important as a source of terrain detail. Shadowed slopes are semitransparent, becoming slightly darker and more contrasting only on the highest mountain crests. Illuminated northwest slopes on the shaded relief interact with the hypsometric tints below, creating lighter tones. The overall effect of these adjustments is lighter shaded relief that has a three-dimensional appearance and that minimizes interference with the background tints. Glancing at the final map, one sees the cross-blended hypsometric tints as the primary information (Figure 3).

\section{CONCLUSION}

Cross-blended hypsometric tints are certainly not a panacea for every map needing to show elevation colors. They are best-suited for small- and mediumscale maps for geographic areas that have distinctly different environments adjacent to one another. A map of North America would be an appropriate use, for example. By contrast, any of the US states east of the Mississippi River do not have enough natural variation by themselves to warrant the technique. Large-scale topographic maps are another inappropriate use. In addition, the softly blended colors of cross-blended hypsometric tints are not ideal for mapping terrain for the precise reading of elevations.

Whether or not to use a map legend on a small-scale map with cross-blended hypsometric tints depends upon its use. For a physical map, the answer is yes. A legend in this case will give readers a general sense of relative elevation and environmental regions. In the case of using cross-blended hypsometric tints as a secondary backdrop for other thematic data—an airline in-flight map, for 
instance- the answer is probably no. In another example, the official map of the US National Park System, which functions primarily as a poster, does not explain the tints in the legend but, appropriately, describes the various park types in detail (see references for URL). Without cross-blended hypsometric tints this map would be duller, less apt to be displayed, and as a consequence the parks possibly less well-known.

The cross-blended hypsometric tints described here are not the only design solution. Varying only the lowland color on otherwise conventional hypsometric tints possibly limits their effectiveness. The yellow and red tints at mid elevations often occur in areas with humid environments, such as the coastal mountains of British Columbia. This may lead readers to wrongly conclude that these areas are arid. One possible solution: the cross blending of revised tints without red at mid elevations. For example, humid areas could use a tonal scale comprised primarily of green, transitioning to light greenyellow and then white at the highest elevations. And in arid areas the scale would start with brown. Patterson (2004) discusses this method for mapping the contiguous United States (see references for URL). One of the challenges of devising cross-blended hypsometric tints in this manner is the potential for drabness. Adding shaded relief comprised of warm yellow-reds on illuminated slopes and blue violet on shadowed slopes could counteract this, brightening the appearance. This is a technique that merits further exploration.

Since being introduced in October 2009, cross-blended hypsometric tints have had 25,172 downloads, surpassing the popularity of other raster datasets on the Natural Earth Data website (see references for URL). By comparison, Natural Earth I, a land cover map of the world, had 13,554 downloads in the same period. Considering that the files are very large, ranging up to $385 \mathrm{MB}$ apiece when compressed, and in geospatial TIF format, casual web surfers probably do not much frequent the site.

Those who make maps presumably are the ones downloading cross-blended hypsometric tints- that the data are free no doubt contributes to their appeal. What remains unknown, however, is whether those who read maps (i.e., the general public) interpret cross-blended hypsometric tints as both elevation and the environment, as is intended. Do people really get it? A forthcoming user study by the authors of this paper will attempt to answer this question.

\section{REFERENCES}

Chilton, S. 2007. Interview on Google Earth Design blog. Accessed June 26, 2011. http://googleearthdesign.blogspot.com/2007/08/steve-chiltoninterview.html

Cohen, J. and C. Small. 1998. "Hypsographic demography: The distribution of human population by altitude.” PNAS USA 95: 14009-14014. 
Da Vinci, L. 1503-04. A Map of Central Italy Accessed June 26, 2011.

http://www.royalcollection.org.uk/eGallery/object.asp?maker=12196\&obj ect $=912277 \&$ row $=436$

Engelmann, G. 1966. “Carl Ritters 'Sechs Karten von Europa'.” Erdkunde 20-2: 104-110.

Gardiner, L. 1976. Bartholomew 150 years. Edinburgh. John Bartholomew \& Sons, Ltd.

Goode's World Atlas. 1983. Espenshade, E.B., Jr. (Ed.). 16th Edition. Chicago, New York, San Francisco: Rand McNally.

Imhof, E. 1924. Die Reliefkarte. Beiträge zur kartographischen

Geländedarstellung. Mitteilungen der Ostschweizerischen GeographischCommerziellen Gesellschaft in St. Gallen.

Imhof, E. 1982. Cartographic Relief Presentation. Steward, H.J. (ed). Berlin, New York: de Gruyter.

Kottek, M., J. Grieser, C. Beck, B. Rudolf, and F. Rubel. 2006. "World Map of the Köppen-Geiger climate classification updated." Meteorologische Zeitschrift 15: 259-263.

Kretschmer, I. 1986. Höhenschichtenkarte. In: Kretschmer, I., Dörflinger, J. and Wawrik, F. (eds.) Lexikon zur Geschichte der Kartographie, 306-308.

Kretschmer, I. 1988. "The first and second Austrian school of layered relief maps in the nineteenth and early twentieth centuries." Imago Mundi 40: 9-14.

Kretschmer, I. 2000. “Naturnahe Farben kontra Farbhypsometrie.” Cartographica Helvetica 21:39-48.

National Geographic-Roper Survey of Geographic Literacy. 2006. Accessed June 26, 2011. www.nationalgeographic.com/roper2006/findings.html

National Park System Brochure Map. Accessed June 26, 2011.

http://home.nps.gov/carto/PDF/NPSmap2.pdf

Natural Earth Data. Accessed June 26, 2011.

www.naturalearthdata.com

Oxford Atlas Project, Oxford University Press-Australia \& New Zealand.

Accessed October 7, 2011.

http://www.oxfordatlasproject.com.au/_data/assets/pdf_

file/0008/155681/OAP3_research_08SEC22.pdf 
Patterson, T. and N.V. Kelso. 2004. "Hal Shelton Revisited: Designing and Producing Natural-Color Maps with Satellite Land Cover Data." Cartographic Perspectives 47: 28-55.

Patterson, T. 2006. Physical Map of the Coterminous United States. Accessed June 26, 2011. www.shadedrelief.com/physical/index.html

Patterson, T. 2004. “Using Cross-blended Hypsometric Tints for Generalized Environmental Mapping.” Accessed June 26, 2011.

http://www.shadedrelief.com/hypso/hypso.html

Patton, J.C. and P.V. Crawford. 1978. “The Perception of Hypsometric

Colours." The Cartographic Journal 15: 115-127.

Thrower, N. 2008. Maps and Civilization: Cartography in Culture and Society ( $3^{\text {rd }}$ ed.) University of Chicago Press.

Wiegand, P. 2006. Learning and Teaching with Maps. London and New York: Routledge.

\section{APPENDIX A}

CROSS-BLENDED HYPSOMETRIC TINTS: CMYK AND RGB COLOR VALUES

\begin{tabular}{|c|c|c|c|c|}
\hline Elev. (m) & Arid & Warm Humid & Cold Humid & Polar \\
\hline 7,000 & $\begin{array}{l}3 c 2 m 2 y 0 k \\
245 r 245 g \text { 245b }\end{array}$ & $\begin{array}{l}3 c 2 m 2 y 0 k \\
245 r 245 g \text { 245b }\end{array}$ & $\begin{array}{l}3 c 2 m 2 y 0 k \\
245 r 245 g \text { 245b }\end{array}$ & Not applicable \\
\hline 6,000 & $\begin{array}{l}\text { 6c 5m 4y 0k } \\
235 \mathrm{r} 235 \mathrm{~g} 237 \mathrm{~b}\end{array}$ & $\begin{array}{l}\text { 6c 5m 4y 0k } \\
235 \mathrm{r} 235 \mathrm{~g} 237 \mathrm{~b}\end{array}$ & $\begin{array}{l}\text { 6c 5m 4y 0k } \\
235 r \text { 235g 237b }\end{array}$ & Not applicable \\
\hline 5,000 & $\begin{array}{l}12 c 9 m 10 y \\
220 r 220 g 220 b\end{array}$ & $\begin{array}{l}12 c 9 m 10 y \\
220 r 220 g 220 b\end{array}$ & $\begin{array}{l}12 \mathrm{c} 9 \mathrm{~m} 10 \mathrm{y} \\
220 \mathrm{r} 220 \mathrm{~g} 220 \mathrm{~b}\end{array}$ & Not applicable \\
\hline 4,000 & $\begin{array}{l}16 \mathrm{c} 14 \mathrm{~m} 16 y \text { Ok } \\
212 \mathrm{r} 207 \mathrm{~g} 204 \mathrm{~b}\end{array}$ & $\begin{array}{l}16 \mathrm{c} 14 \mathrm{~m} 16 y \text { Ok } \\
212 \mathrm{r} 207 \mathrm{~g} 204 \mathrm{~b}\end{array}$ & $\begin{array}{l}16 \mathrm{c} 14 \mathrm{~m} 16 y 0 k \\
212 \mathrm{r} 207 \mathrm{~g} 204 \mathrm{~b}\end{array}$ & $\begin{array}{l}4 \mathrm{c} 2 \mathrm{~m} \text { Oy 0k } \\
241 \mathrm{r} 245 \mathrm{~g} 254 \mathrm{~b}\end{array}$ \\
\hline 3,000 & $\begin{array}{l}17 \text { c } 22 \mathrm{~m} 27 y \text { 0k } \\
212 \mathrm{r} 193 \mathrm{~g} 179 \mathrm{~b}\end{array}$ & $\begin{array}{l}17 \text { c } 22 \mathrm{~m} \mathrm{27y} \mathrm{0k} \\
212 \mathrm{r} 193 \mathrm{~g} 179 \mathrm{~b}\end{array}$ & $\begin{array}{l}17 \text { c } 22 \mathrm{~m} 27 y 0 k \\
212 \mathrm{r} 193 \mathrm{~g} 179 \mathrm{~b}\end{array}$ & $\begin{array}{l}5 \mathrm{c} 2 \mathrm{~m} \text { Oy Ok } \\
239 \mathrm{r} 243 \mathrm{~g} 252 \mathrm{~b}\end{array}$ \\
\hline 2,000 & $\begin{array}{l}17 \text { c } 27 \mathrm{~m} 34 \mathrm{y} 0 \mathrm{k} \\
212 \mathrm{r} 184 \mathrm{~g} 163 \mathrm{~b}\end{array}$ & $\begin{array}{l}17 \text { c } 27 \mathrm{~m} 34 \mathrm{y} 0 \mathrm{k} \\
212 \mathrm{r} 184 \mathrm{~g} 163 \mathrm{~b}\end{array}$ & $\begin{array}{l}17 \mathrm{c} 27 \mathrm{~m} 34 \mathrm{y} 0 \mathrm{k} \\
212 \mathrm{r} 184 \mathrm{~g} 163 \mathrm{~b}\end{array}$ & $\begin{array}{l}13 \mathrm{c} 7 \mathrm{~m} \text { ly } 0 \mathrm{k} \\
218 \mathrm{r} 226 \mathrm{~g} 239 \mathrm{~b}\end{array}$ \\
\hline 1,000 & $\begin{array}{l}17 \mathrm{c} 17 \mathrm{~m} 29 \mathrm{y} 0 \mathrm{k} \\
212 \mathrm{r} 201 \mathrm{~g} 180 \mathrm{~b}\end{array}$ & $\begin{array}{l}17 \mathrm{c} 17 \mathrm{~m} 29 \mathrm{y} 0 \mathrm{k} \\
212 \mathrm{r} 201 \mathrm{~g} 180 \mathrm{~b}\end{array}$ & $\begin{array}{l}17 \mathrm{c} 17 \mathrm{~m} 29 \mathrm{y} 0 \mathrm{k} \\
212 \mathrm{r} 201 \mathrm{~g} 180 \mathrm{~b}\end{array}$ & $\begin{array}{l}19 \mathrm{c} 10 \mathrm{~m} \mathrm{3y} \mathrm{0k} \\
201 \mathrm{r} 214 \mathrm{~g} 231 \mathrm{~b}\end{array}$ \\
\hline 600 & $\begin{array}{l}21 \mathrm{c} 22 \mathrm{~m} 30 \mathrm{y} 0 \mathrm{k} \\
202 \mathrm{r} 190 \mathrm{~g} 174 \mathrm{~b}\end{array}$ & $\begin{array}{l}36 \mathrm{c} 13 \mathrm{~m} 38 \mathrm{y} 0 \mathrm{k} \\
169 \mathrm{r} 192 \mathrm{~g} 166 \mathrm{~b}\end{array}$ & $\begin{array}{l}31 \mathrm{c} 16 \mathrm{~m} 29 \mathrm{y} 0 \mathrm{k} \\
180 \mathrm{r} 192 \mathrm{~g} 180 \mathrm{~b}\end{array}$ & $\begin{array}{l}26 \mathrm{c} 15 \mathrm{~m} 4 \mathrm{y} 0 \mathrm{k} \\
185 \mathrm{r} 201 \mathrm{~g} 224 \mathrm{~b}\end{array}$ \\
\hline 200 & $\begin{array}{l}31 \mathrm{c} 29 \mathrm{~m} 36 \mathrm{y} 0 \mathrm{k} \\
180 \mathrm{r} 170 \mathrm{~g} 158 \mathrm{~b}\end{array}$ & $\begin{array}{l}49 \mathrm{c} 12 \mathrm{~m} 43 \mathrm{y} 0 \mathrm{k} \\
134 \mathrm{r} 184 \mathrm{~g} 159 \mathrm{~b}\end{array}$ & $\begin{array}{l}45 \mathrm{c} 19 \mathrm{~m} 32 \mathrm{y} 0 \mathrm{k} \\
145 \mathrm{r} 177 \mathrm{~g} 171 \mathrm{~b}\end{array}$ & $\begin{array}{l}32 \mathrm{c} 17 \mathrm{~m} 8 \mathrm{y} 0 \mathrm{k} \\
171 \mathrm{r} 192 \mathrm{~g} 213 \mathrm{~b}\end{array}$ \\
\hline 50 & $\begin{array}{l}35 \mathrm{c} 33 \mathrm{~m} 39 \mathrm{y} 1 \mathrm{k} \\
170 \mathrm{r} 160 \mathrm{~g} 150 \mathrm{~b}\end{array}$ & $\begin{array}{l}56 \mathrm{c} 17 \mathrm{~m} 47 \mathrm{y} 1 \mathrm{k} \\
120 \mathrm{r} 172 \mathrm{~g} 149 \mathrm{~b}\end{array}$ & $\begin{array}{l}52 \mathrm{c} 24 \mathrm{~m} 38 \mathrm{y} 1 \mathrm{k} \\
130 \mathrm{r} 165 \mathrm{~g} 159 \mathrm{~b}\end{array}$ & $\begin{array}{l}36 \mathrm{c} 22 \mathrm{~m} \mathrm{10y} 0 \mathrm{k} \\
164 \mathrm{r} 180 \mathrm{~g} 203 \mathrm{~b}\end{array}$ \\
\hline 0 & $\begin{array}{l}39 \text { c } 36 \mathrm{~m} 42 \mathrm{y} 2 \mathrm{k} \\
160 \mathrm{r} 152 \mathrm{~g} 141 \mathrm{~b}\end{array}$ & $\begin{array}{l}59 \mathrm{c} 20 \mathrm{~m} \mathrm{51y} 1 \mathrm{k} \\
114 \mathrm{r} 164 \mathrm{~g} 141 \mathrm{~b}\end{array}$ & $\begin{array}{l}56 \mathrm{c} 25 \mathrm{~m} 41 \mathrm{y} 1 \mathrm{k} \\
120 \mathrm{r} 159 \mathrm{~g} 152 \mathrm{~b}\end{array}$ & $\begin{array}{l}43 \mathrm{c} 27 \mathrm{~m} \mathrm{12y} \mathrm{0k} \\
149 \mathrm{r} 169 \mathrm{~g} 196 \mathrm{~b}\end{array}$ \\
\hline-400 & $\begin{array}{l}44 \mathrm{c} 42 \mathrm{~m} 45 \mathrm{y} 5 \mathrm{k} \\
146 \mathrm{r} 136 \mathrm{~g} 129 \mathrm{~b}\end{array}$ & $\begin{array}{l}62 \mathrm{c} 25 \mathrm{~m} 51 \mathrm{y} 3 \mathrm{k} \\
106 \mathrm{r} 153 \mathrm{~g} 135 \mathrm{~b}\end{array}$ & $\begin{array}{l}59 \mathrm{c} 30 \mathrm{~m} 44 \mathrm{y} 3 \mathrm{k} \\
112 \mathrm{r} 147 \mathrm{~g} 141 \mathrm{~b}\end{array}$ & Not applicable \\
\hline
\end{tabular}


